\title{
Communist Objects and the Values of Printed Matter
}

\section{Nicholas Thoburn}

He does not know how to act with the world of Things.

-Boris Arvatov

It is to the credit of recent research in historical and cultural studies of "the book" and the practitioner field of book arts that the rich and dynamic materiality of print media has emerged to critical perception from beneath the surface of the linguistic text. ${ }^{1}$ The book is now approached as a mutable arrangement of conceptual, tactile, visual, textual, spatial, and temporal properties. But is it possible to discern a politics of the book if the book is considered no longer only as a vehicle for content but as a complex object? Jacques Rancière's The Nights of Labor offers an enticing way into this question. Here he attends to the strange literary and aesthetic artifacts created by nineteenth-century workerpoets, -painters, and -writers in their efforts to breach the separation between manual and intellectual labor and so "exorcise their inexorable future as useful workers." For Rancière, these objects created at night by "a few dozen 'nonrepresentative' individuals" confound the capitalist imperatives of class identity and the constraining subjectivity of the workers' movement: they are "so many hieroglyphs of the anticommodity." But as such, these anomalous media objects are fleeting, near-impossible entities, for they can constitute only a momentary or projected desertion from the "dictatorship of king work."

A poem, a painting, a piece of printed matter, then, can be an "anticommodity," or at least an indication of such - a most political object. But Rancière does not pursue this formulation further, or attend to the dense 
materiality of media. And that is the concern of this article: to consider the material properties of political print media through a figure of the anticommodity, what I call here the "communist object." I investigate the problematic of the communist object through Russian Constructivist approaches to the "intensive expressiveness" of matter, Walter Benjamin's analysis of the "collector" and his critique of use value, and the confounding dynamics of the "fetish." The principal contours of the communist object, drawn out from the different strands of the discussion, are set out at the end of the section "The Useless Object." But essentially, the communist object is an inorganic material entity that destabilizes the commodity attributes of property and utility and their correlated patterns of subjectivity and association. It posits instead an excessive materiality in a communism of organic and inorganic process.

I would make a brief methodological aside here. The communist object is of course also a conceptual perspective on the world of objects, but it is one that emphasizes the capacities of objects to have transformative effects on human sociality and thought that are not predetermined by the form of the human subject. This orientation follows a materialist understanding of subject and object as products of mutable arrangements of organic and inorganic matter, arrangements that operate at macro and micro scale and have complex and various agential properties. While focusing on the object, I do not intend, then, to perpetuate a dichotomy with the subject; indeed, the materialist figure of the communist object is attentive to the way human and object association can undo the capitalist patterns of subjectivity that institute that dichotomy in the first place.

After setting out the communist object, I then explore printed matter through this figure. I focus less on the book and what Benjamin calls its "pretentious, universal gesture" than on one of the more "inconspicuous forms" or "fringe areas," to use his characterization of the vital margins of literary production: the media object of the small-press pamphlet. ${ }^{4} \mathrm{I}$ draw on interviews with producers and an archivist of contemporary smallpress projects of nondoctrinal communist persuasion, Fabian Tompsett of Unpopular Books, Chris of South London's 56a Archive, and Jakob Jakobsen of Infopool. Analysis of these projects forms the core of the later parts of this article.

\section{The Intensive Expressiveness of the Object}

An investigation into the potentiality of the communist object has to work against a dominant image of the place of things or objects in Marxism, that of communism as an ascetic order. This image is associated with an at best simplified reading of Marx's diagnosis in Capital of the fetish nature of commodities, where, in a dichotomous relation between humans 
and objects, social relations between things determine thinglike relations between people. Marxism in this image would seek to revalue people against the capitalist valorization of things, in the process stripping the object of its seductive, diverting capacities and subjecting it to rational order and the plan. It is to Bolshevik philosophy and official Soviet culture that one might understandably turn for empirical referents of this image of ascetic socialism. But it is also in the midst of early Soviet art and culture that an especially innovative formulation of communism and the object can be found.

As Christina Kiaer has recently argued, the problem of the material object and its sensuous and transformative relation with the human had a key place in Russian Constructivism, whose materialism she characterizes as having an "obsessive, even unseemly emphasis on . . . things themselves." Indeed, writing home from the 1925 Paris International Exposition of Modern Industrial and Decorative Arts, Aleksandr Rodchenko quite astonishingly presents capitalism as the exploitation of the human and the object, and projects their possible relation as one of equality: "The light from the East is not only the liberation of workers, the light from the East is in the new relation to the person, to woman, to things. Our things in our hands must be equals, comrades, and not these black and mournful slaves, as they are here."6

Kiaer identifies what she calls the Constructivist "socialist object" as an unstable entity emergent from a set of intersecting themes and contexts: art into industrial production toward the transformation of everyday life (the "expedient," utilitarian object) with all the associated questions about the place of the artist in industry; an achieved socialist revolution that projected beyond property ("not . . the elimination of material objects, but . . . the elimination of a possessive relation to them"); and the persistence of the commodity form (under the New Economic Policy's reintroduction of private capital, and the global context of the endurance of capitalist commodity culture). ${ }^{7}$ One of the many strengths of Kiaer's argument is that she positions the Constructivist object in the midst of the affective field of the commodity, where desiring relations to objects in capitalism are less to be negated than explored, teased out, deployed, and transcended in communist material culture.

It is apparent, then, that Constructivism is a highly complex and precarious entity traversed by many points of tension, but the importance for my argument is the way the object features here as a sensuous entity in material equality with the human, the object as "comrade" and "coworker." These features of the Constructivist object are explicitly addressed in Boris Arvatov's 1925 essay "Everyday Life and the Culture of the Thing."

Against idealist tendencies in Marxist philosophies of culture that foreground social consciousness at the expense of the material everyday, ${ }^{9}$ 
Arvatov places the "universal system of Things" — the field of "production and consumption of material values" - firmly at the center of social life. ${ }^{10}$ The scope of the essay, however, extends beyond this foregrounding of the material everyday, for here Arvatov sets out the possibility of a proletarian material culture "imbued with the deepest sense of Things," even of the "becoming . . . thinglike" of communist politics. ${ }^{11}$ The structure of consumption in capitalist culture as a private, individual arena separated from machine-rich collective production creates an object that is severed from an experience of its genesis, its manifold material relations, and which is instead constituted as an isolated, "finished," and iterable unit of private property. ${ }^{12}$ In this manifestation, style and form become "clichéd," subject to "imitative conservatism" in a world where the potentially dynamic object is reduced to an arrangement in the affectations of bourgeois indvidualism. ${ }^{13}$ This has effects too on the object's sensory form. A property relation to the thing, for all its affective power in the composition of bourgeois identity, is a reduction of the human sensorium. As Marx puts it, "all the physical and intellectual senses have been replaced by the simple estrangement of all these senses - the sense of having." ${ }^{14}$ For Arvatov, then, the object consumed as a commodity is a dead and solitary object: "The Thing as an a-material category, as a category of pure consumption, the Thing outside its creative genesis, outside its material dynamics, outside its social process of production, the Thing as something completed, fixed, static, and, consequently, dead - this is what characterizes bourgeois material culture." 15

It is worth briefly reflecting on the approach to Marx's fetishism of commodities implicit in this argument. As a structure of feeling, commodity fetishism here is not veneration of the object per se, but of the objectas-private-property, a foreclosed, isolated entity sundered from dynamic relations with humans and machines. In turn, if we recall the centrality of private property to the bourgeois subject — the "liberty" of the "restricted individual, restricted to himself" - the love of property in commodity fetishism is the affective structure of human isolation, isolation not just from a fully social relation with other humans but also from the expansive world of inorganic matter. ${ }^{16}$ For Arvatov, this "a-material" manifestation of the object in consumption is a structural complement to its mode of existence in production, where exchange value, not material quality, is the object's determining aspect. As a structure of production, then, commodity fetishism is the social veneration not of things as material, sensuous entities but of abstract value. As to the "mystical" or "fetish" capacity of the commodity to "have a life of [its] own," one that determines human sociality, Arvatov would presumably agree with Marx's careful, demystifying argument that this is a power not of the sensuous object but of the object as expressive of value, value that is misapprehended as a product of the object due to the dynamics of commodity circulation. ${ }^{17}$ 
Arvatov's communist material culture of the object is, by contrast, oriented toward an elimination of the "rupture between Things and people" at the level of their dynamic interaction, and in a fashion that gives agency to the object - that retrieves it from "immobility," "inactivity," and the "absence . . . of any element of instrumentality" — in the practical, psychological, and sensual reconfiguration of the human. ${ }^{18}$ From the foreclosed sensorial scope of the commodity thing, communism here, in Marx's ecstatic expression, is "the complete emancipation of all human senses and attributes" as enabled precisely through an experience of the object: "To be sensuous, i.e. to be real, is to be an object of sense, a sensuous object, and thus to have sensuous objects outside oneself, objects of one's sense perception. To be sensuous is to suffer (to be subjected to the actions of another)." 19 As Peter Pels remarks, this passage does not at all exclude the possibility that "to be sensuous is "to be subjected to the actions of another thing." "'20

It is the movement away from the property relation in the sharing of complex technical objects that for Arvatov enables this opening of the isolated and clichéd commodity to a social community of things and people. He sets out two aspects of this new immersed or integrated object. First, the material qualities of things come to the fore, something the human acts upon as form cedes to function: "Glass, steel, concrete, artificial materials and so on were no longer covered over with a 'decorative' casing, but spoke for themselves. . . The thing was dynamized. Collapsible furniture, moving sidewalks, revolving doors, escalators, automat restaurants, reversible outfits, and so on constituted a new stage in the evolution of material culture. The Thing became something functional and active, connected like a co-worker with human practice." 21

I will return to the issue of function below, but it is important to underscore the strong presence here of a culture of materials, what Arvatov elsewhere describes as an engagement with matter at an "elemental" level, at its "intensive expressiveness." 22 One might say further that materials here overtake the author, who becomes a reader or agent of inorganic matter; Vladimir Tatlin, for instance, "reconfigure[s] himself as the material's assistant." 23 The approach is enhanced by a second aspect, Arvatov's concern with the "natural" life of things, their expression of the "powerful and indefinitely expanding energies of the material sphere." 24 While Arvatov looks to the institutional research and production cultures of the American technical intelligentsia for tendencies to communist material culture, the technical object here still remains "self-sufficient" and "retired within itself" to the extent that in industrial culture it is severed from its relation to nature. As such, the "dynamic-laboring structure" of the object "and its living force are never simultaneously present; thus both become 'soulless.'”25 
It is quite possible that in Arvatov's fascinated approach to the "intensive expressiveness" of the object there are indications of what Gilles Deleuze and Félix Guattari characterize as the "nonorganic life" of matter and its associated "artisans," those who, against the matter-form hylomorphic model, work with or follow the singularities of matter and its traits of expression. ${ }^{26}$ But Arvatov's appreciation of the expressive life of matter vies with a dominant imperative in his work, and Constructivism more widely, toward the utilitarian or "expedient" object. The proper environment of the Constructivist object in mass production and its part in the transformation of everyday life through the rational reorganization of Soviet society is the profound promise of Constructivism, but also its most problematic feature. Having foregrounded the agency of matter, now even the most abstract and experimental material values - for instance, the "qualities of pure color, line" — become subject to the plan and the imperatives of utility and production against any "unorganized arbitrariness." ${ }^{27}$ As Deleuze and Guattari observe, Constructivism, in keeping with Bolshevik orthodoxy, conceives of the transformation of capitalist industry to socialism at the level of collectivization, the transfer of ownership of the forces of production from the capitalist class to the State. ${ }^{28}$ As such, it fails to appreciate the immanence of capitalist imperatives in the production process: it leaves the capitalist relations of production - the domination of the worker by the technical machine and the separation of production from consumption - largely untroubled, as Lenin's advocacy of Taylorism and Trotsky's "militarisation of labor" confirm. ${ }^{29}$

\section{The Useless Object}

What, then, might be a communist object, a material coworker and comrade, that is not traversed by the imperatives of expediency and production? Walter Benjamin's speculations on the figure of the "collector" help answer this question, for here he precisely foregrounds a critique of "use." For Benjamin, the "Sisyphean task of divesting things of their commodity character" cannot appeal to function or "use value." 30 Indeed, the proper materialist approach "entails the liberation of things from the drudgery of being useful." ${ }^{31}$ Benjamin deduces this point from a passage in Marx: "Private property has made us so stupid and one-sided that an object is only ours when we have it, when it exists for us as capital or when we directly possess, eat, drink, wear, inhabit it, etc., in short, when we use it." 32

Use, in this formulation, is what patterns and regularizes the object for iteration in the commodity mode. Use is not an exteriority to exchange value but the foreclosed metabolic and sensory experience of the object formed within and functional to the individualized, everyday life of capital: the uses of objects are a "means of life; and the life they serve is the 
life of private property, labour and capitalization." ${ }^{33}$ This is implicit in the Constructivist critique of the reduced sensorial scope of bourgeois things, but for Benjamin the communist alternative must be no less removed from expediency.

Benjamin detects signs of a properly "useless" relation to objects in the obscure practices of the collector. In a fashion that is initially not so different from Arvatov, Benjamin presents the collector as possessing a "tactile instinct," an immersive relation that complements the optical sense with touch, handling, smell, contemplation, love, and imagination, and as one who experiences the object as an affective "strike" on the sensorium. ${ }^{34}$ As Esther Leslie argues, this is "an intensified perception, bound up with shock, impact and curiosity," one that at the level of everyday material culture complements the enhanced technological perception Benjamin famously detects in photography and cinema: "everything-even the seemingly most neutral-comes to strike us." ${ }^{35}$ But it is not the functional, useful properties of objects that are experienced in this way. These "physiognomists of the world of objects" appear to value everything but the object's usefulness: "The period, the region, the craftsmanship, the former ownership - for a true collector the whole background of an item adds up to a magic encyclopedia whose quintessence is the fate of his object." ${ }^{36}$

This mode of association with objects is found not in Arvatov's advanced plane of social production, but in the unstable and momentary arrangement of fragments Benjamin calls the "collection." The collection is a community of objects in a relation that is the "diametric opposite of any utility." ${ }^{37}$ It is a "circumscribed area" within which a sensorial field is opened that overtakes the collector: "Not that [objects] come alive in him; it is he who lives in them." ${ }^{38}$

What does Benjamin add to Arvatov? The point for my argument is not, of course, that the communist object is only realized in a collection, or indeed that communists need to become collectors. Rather, Benjamin shows that it is not enough to ward off exchange value to undo the commodity, but that the object's use must also remain in suspension if its rich singularity - what Guattari might call its "quasi-animistic speech effect" - is to come forth. ${ }^{39}$ In addition, by placing the object in the resolutely nonproductive permeable contour of the collection, Benjamin - in keeping with his communist critique of the social democratic and vulgar Marxist glorification of labor ${ }^{40}$ - suggests that the communist object resists the patterns of work that the expedient object (be it capitalist or socialist) demands. There is a development here too of Arvatov's concern with nature, for in the appreciation of the particular "fate" of the object-its orbits, its streams of past and future - the collector is also attuned to the dissipative properties and destructive processes of matter. ${ }^{41}$ Against the delimiting temporal patterns of commodity circulation, the collector's 
mode of relation thus opens to the many and singular durations of things, so displaying an "anarchistic, destructive" passion, a "wilfully subversive protest against the typical, classifiable." 42

The value of uselessness can be brought into greater focus through consideration of the Surrealist "found object," perhaps the most influential avant-garde formulation of the object. Certainly, Benjamin places great stress on the revolutionary transformation of things - "enslaved and enslaving objects" - in Surrealism, a movement that "bring[s] the immense forces of 'atmosphere' concealed in . . . things to the point of explosion." 43 And these are objects that slip out of and rise up against the circuits of commodity consumption; indeed, André Breton characterizes such objects of "prolonged sensual contact" as precisely "useless." 44 Yet the found object is interpreted through, and determined by, chains of psychic and sexual association that are, in their particular orbit, no less determining than that of the Soviet plan (as is especially clear in Breton's account in Mad Love of flea market finds with Alberto Giacometti). ${ }^{45}$

Denis Hollier's assessment of the dissident Surrealist journal Documents indicates a more fruitful resonance with Benjamin's object through the modality of the "document" and Georges Bataille's approach to use value and fetish. For Hollier, the journal's deployment of the cultural artifact (abattoirs, Hollywood film stills, prayer scrolls, coins, flies, flowers) as a "document" signifies a realist "condemnation of the imagination"; not a sur-real experience, the document in its alien heterogeneity presents an antimetaphorical "shock-value." 46 In this, Hollier irreverently posits the fetish — "the irreplaceable, untransposable object" — as the proper use value of the object: “' 'I challenge,' writes Bataille, 'any art lover to love a canvas as much as a fetishist loves a shoe." "47

If one keeps in mind that it is not the psychoanalytic modality of the fetish being developed here (despite Bataille's classical example), then Hollier's formulation is most helpful. As Pels elucidates in his reckoning with “the spirit of matter" (working with William Pietz's exemplary three-part work on the fetish in the journal Res), the fetish is a destabilizing object, an anomalous singularity whose "lack of everyday use and exchange values makes its materiality stand out" and "threatens to overpower its subject."48 In this sense the fetish is close to Benjamin's collected artifact, an excessive and unsettling materiality. But the category of the fetish also helps highlight how the untrammeled materiality of the communist object exists not only in the object and its encounters but always also in tension with capitalist regimes of value. As Pietz shows, both as "object" and "idea," the fetish is a "cross-cultural" entity, one "arisen in the encounter of radically heterogeneous social systems" and having no proper existence in a "prior discrete society." 49 The modern, Enlightenment meaning of the concept lies in the efforts of seventeenth-century European merchants to 
account for what they perceived as the irrational attribution of value in West Africa to arbitrary objects; what was valued was not the universally exchangeable object of political economy, but "any 'trifle' that 'took' an African's 'fancy." "50 It is, then, only in the encounter of noncapitalist and capitalist value systems that an entity we could call a "fetish" exists. And so to affirm the fetish today — to give a positive valence to this category of colonial misrepresentation and control, and no longer to use it to name a relation in need of demystification - is to hold both capacities together, its excessive materiality and its disruptive interaction with capitalist regimes of value:

The fetish is an object that has the quality to singularize itself and disrupt the circulation and commensurability of a system of values. This capacity to singularize itself in relation to an ongoing process, and thereby to arrest it, is what makes the fetish into an "other thing." . . . its singularity is not the result of sentimental, historical or otherwise personalized value: The fetish presents a generic singularity, a unique or anomalous quality that sets it apart from both the everyday use and exchange and the individualization or personalization of objects. ${ }^{51}$

With the fetish we have come full circle: from the "commodity fetishism" that is justly challenged and unmasked in the property relation to a fetishism of unbound and disruptive materiality in the object. At risk of being overly schematic, this stage invites a statement of the principal features of the communist object drawn from the discussion so far. As "comrade" and "coworker," the communist object exists on a plane of equality with the human, so amplifying the sensory exchange between organic and inorganic matter and unsettling the affective organization of the capitalist subject. It is neither an object of utility or property - closed and dead as these commodity values are - but exists in openness to undetermined circulation, alteration, and destruction. This is a circulation that is not found in laboring practice and market exchange but in fleeting and permeable arrangements that actualize the object's singularity, its intensive expressiveness. Yet the communist object is not a rarefied other to the commodity; the passional bond it produces emerges in the midst of everyday objects and desires activated in commodity culture. As such, it has something of an anomalous, fetish character; it expresses a spirit of matter that - in its Sisyphean efforts toward the overcoming of capitalist relations - disturbs and disrupts established regimes of value. Of course, the communist object is not a fully achieved entity, but a moment in the life of an object. And it is in turn enmeshed with, and shaped by, the singular properties of the particular object in which it is instantiated. While displaying these general characteristics or tendencies, the communist object is existent, then, only in its manifold concrete expressions. 


\section{Book Works}

How might printed matter be explored through the figure of the communist object? The book has a strong affective allure; indeed, for some "the archetype of the book is so powerful that it has a way of reaching out and grabbing you and taking you into a dimension of itself." 52 Such destabilizing seductions are a principal concern of the twentieth-century art form of the "artists' book" or "book work." This art form offers a productive way into the field of the printed communist object because it troubles the principal "use" of the book - as a vehicle for the transmission of content - and attends instead to the material complexity of the book as artifact. The book work is a mode of aesthetic production that takes as its object the conceptual, affective, temporal, spatial, and formal qualities of the book. As Johanna Drucker defines it in her seminal book on the varied manifestations of this art form, the artists' book is an original work that "integrates the formal means of its realization and production with its thematic or aesthetic issues." ${ }^{53}$

For instance, though predating the book work proper, the concern in Russian Futurism with the phonic, graphic, hieroglyphic qualities of writing expounded in the concepts of "the word as such" and zaum ("transreason") found expression in books that were conceived not as means of communication but as active, polysensual objects, as "living organisms." 54 These often rough-hewn, self-published works assembled of lithographed manuscripts, handwriting, linocuts, hectography, rubber stamps - works that tended to unsettle the distinction between word and image - were not to be read as such; they were to "see, listen to, and feel." 55 As Jared Ash and Nina Gurianova show, ${ }^{56}$ Russian Futurist books, developing from an interest in folk culture, ritual-related art, and the ornate objects and haptic styles of nomadic peoples (especially in Aleksei Kruchenykh's work, and that of David and Nikolai Burliuk), take on a magical, shamanic aspect that in the immediacy of their sensual and phonic expression is seen to access an elemental, chaotic plane: "Transrational language is a language of pre-inscription, the rustling chaos of poetry, pre-book, pre-word chaos out of which everything is born and into which everything disappears." ${ }^{57}$

Such orientation toward a dynamic textual matter also has an extraordinary expression in Antonin Artaud's paper "spells" or "gris-gris," 58 sent from Dublin and France in 1937 and 1939 as protective or imprecatory devices to friends, doctors, and public figures — seven are known to exist, including one that remained unsent to Hitler. ${ }^{59}$ Agnès de la Beaumelle interprets these objects against an analytic separation of artifact and text to show how sign, color, word, lettering combine with the material of the paper, perforated and frayed with burns, to produce "a surface that is as much active as acted upon," and one that is intended to act physically upon 
its interlocutors. ${ }^{60}$ It pays to quote at length Beaumelle's presentation of the 1939 works sent from the Ville-Évrard asylum:

Their imprecatory violence now resides more in the physical state of the missive than in the words. Inscribed with a thick ink crayon in purple, the different signs (crosses, stars, triangles, spirals in the shape of serpents, the cabalistic significance of which Artaud knew well) proliferate in all directions, invade the center of the paper itself, break the continuous thread of writing drawn with the same ink crayon: fragments of writing and drawn pictograms henceforth form one body. Not only that: knots, amorphous clusters of crayon, seem to respond in counterpoint, proceeding from the same charge of aggression, to the holes produced by burning the paper (the edges of which are also ravaged); and traces of violent shades of yellow, blue, and red (Artaud also knew the symbolism of colors: these are the colors of death) intensify by their physical presence the imprecatory force of the words. These are no longer simple votive letters but true magical objects, to be handled while making ritualistic gestures ...., which can "illuminate themselves," like "gris-gris." 61

These manifestations of printed matter are evidently traversed by political themes, and as the book work has emerged as an independent art form from the 1960s and 1970s it has been in close association with the critique of the art institution and the art commodity, the politics of the democratic multiple, antiauratic practice, and sexual politics. However, the book work remains largely located within the orbits of art practice. While maintaining a proximity to the perceptual frames of book arts, I want to use the figure of the communist object to explore instead printed artifacts whose principal orientations are more directly constituted in the field of political — or, indeed, communist - media. This is a field where the aesthetic aspects of media are rarely raised, subject as the field tends to be to a delimiting and anemic understanding of communication as "counterinformation." My focus is the small-press pamphlet, a rather prosaic media object yet one that has had a persistent presence in political cultures (albeit in variable ways) for some four hundred years.

The essay considers different attributes of the pamphlet through the themes of fragmented circulation, emergent association, physical composition, ephemeral duration, and commodity seduction. Each section holds together a specific attribute of the pamphlet with one or more features of the concept of the communist object. It does so in a fashion that seeks an exchange between object and concept, expanding understanding of each while maintaining a sense of the processual openness inherent to the concept. Some of the following sections also indicate specific interventions of the pamphlet-as-object in the wider social field. For instance, the section "Vulnerable Powers of Institution" holds together the pamphlet's 
attributes of emergent self-institution with the communist object's mode of intense association and its resistance to the closure of the property relation. In the process, I show the pamphlet making a critical intervention in the contemporary art institution's efforts in the valorization of noncommercial cultures.

In what follows I say little about "content" (artificially, since this is as much an aspect of the materiality of the printed media object as anything else I consider). I would ask the reader unfamiliar with these projects to take it as given that the content of the Unpopular Books and Infopool pamphlets has a nondoctrinal communist orientation (as expressed through diverse topics, be it a photographic essay on Britain in order to discover America by Stewart Home, or a Left communist critique of the political concept of "autonomy" from the French journal Feune Taupe). In a general sense, then, there is a reflexive exchange in the pamphlets between content and form. However, my interest here is in approaching the breadth of material properties of the pamphlet, and, given the limits of an essay, the casualty of this approach - for once - is a sustained analysis of content.

\section{Compact Media and Fragmented Circulation}

In its resistance to determining patterns of exchange and use, the communist object must circulate with a degree of autonomy. The particular mobility of the pamphlet, its manner of circulation, can be discerned through contrast with the journal. An effective journal, as Antonio Negri reflects on Futur Antérieur, is an open survey of the world:

A good journal is like an octopus, continually reaching out and pulling in the theoretical and historical happenings in the environment in which it lives. This journal had a soul - a passionate soul which tried to absorb everything in the world around it which offered theoretical interest, a political choice, an ethical dimension, or simply a joy of life. The soul of a journal is its radical determination to give meaning to everything it touches, to build it into a theoretical tendency, to embrace it within a mechanism or practical activity. ${ }^{62}$

The pamphlet is quite different. Rather than prodigious absorption, it tends to take one problem or theme as its concern; one of the defining experiences of reading a pamphlet is encountering a specific and focused discourse that is unmoored from a known and structured critical environment. Corresponding to this limited or particular focus, the pamphlet is less an extension in space than a fragment, an isolated unit. It circulates without the institutional and temporal structures that order and distribute a journal through time and across space and is instead determined by varied and disjunctive flows and associations - friendships, chance encounters, political events. Drucker presents this as an aspect of printed 
matter that book art makes its own, an "independent life," "a potent autonomy," an "animate quality": "Books, because they have the capacity to circulate freely, are independent of any specific institutional restraints (one finds them in friends' houses, motel rooms, railroad cars, school desks). They are low maintenance, relatively long-lived, free-floating objects." ${ }^{3}$ Though the pamphlet lacks the durability of the book, in its self-published, unmarketed, and often extracommercial properties it is a clear exemplar of much of this characteristic of the book. It is the point foregrounded in Iain Sinclair's discussion of the London Psychogeographical Association (LPA) Newsletter, a project closely associated with Fabian Tompsett of Unpopular Books: "This anonymous, unsponsored, irregular, single-sheet squib is probably the most useful of all London's neighbourhood tabloids. And certainly the most entertaining. It has no fixed cover price and no distribution. If you need it, it finds you." 64

Sinclair may be guilty of imputing intention to the object here, but the nature of these mobile fragments is that most often one is unaware of them until the moment of encounter - an encounter from which "need," or other associational affects, is a product. Rather than "reaching out and pulling in" the world, the pamphlet as fragment holds back from it, circulating as a closed and compact object. This compact condition has an aesthetic quality, as the small-press Guestroom indicates when it describes its core interest as constituted on "the love of books, . . . the compactness of the space they create." 65 It is a feature central to Mallarmé's understanding of the book. If the journal in Negri's characterization suggests one pole of Mallarmé's book - “all earthly existence must ultimately be contained in a book" - the pamphlet tends toward another, the book's dense and compact nature, its "folding" of time and matter: "their thickness when they are piled together; for then they form a tomb in miniature for our souls." 66 It is in this latter pole that Deleuze sees Mallarmé's true achievement, the book as "monad" and "fragment," "that could sustain as many dispersions as combinations." 67 As a monad - a dense and self-enclosed world - the pamphlet circulates as a charged potential, a potential that unfolds in encounters that generate their own spatiotemporal consistency.

\section{Vulnerable Powers of Institution}

The compact nature of the pamphlet and its mode of circulation correspond to a certain intimacy in its encounters, in the permeable association that it constitutes. This affective aspect of printed matter - what Drucker calls "the densely informative immediacy and intimacy of the experience provided by books" 68 — has a prominent place in the understanding of the pamphlet developed by Infopool, and is especially evident in its account of a mediated encounter with London's Tate Modern. 
Based at times in London and Copenhagen, Infopool is a collaborative writing, print, and Internet project established in 2000 by Jakob Jakobsen. It follows a general commitment to self-publishing as "a vector of activity and thought - usually fueled by pleasure/disgust/lack," and an investment in the wider processual and associational properties of media across the boundaries of art and politics. ${ }^{69}$ Infopool has sometimes intersected with the research, exhibition, and social spaces of the East London Info Centre (1998-99) and the Copenhagen Free University (2001-7), organized by Henriette Heise and Jakobsen. ${ }^{70}$ The pamphlets themselves are approximately A5-size with metallic-silver covers that are uniform except for the number and date of the issue.

As part of its 2001 exhibition Century City, the Tate Modern included doctored Infopool pamphlets: three issues were collated as one, bound in a new hardback cover that was renumbered accordingly, and threaded on a presentation wire. Infopool was neither consulted nor notified about the exhibition or

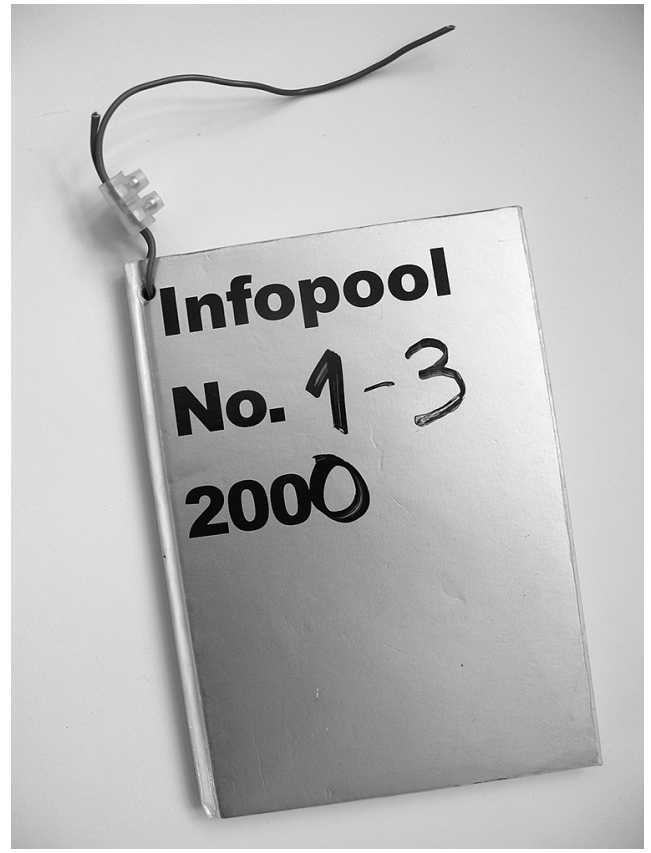

Figure 1. Reappropriated Infopool. Courtesy of Infopool alteration of the pamphlets, and responded by reappropriating them from the museum display with a similar absence of consultation: "We picked the pamphlets up on Friday February 9th. To negotiate their exit would have taken too long" (figure 1)..$^{71}$ The account Infopool provides is particularly interesting for its assessment of the different modes of institution and value constituted in Infopool and the art museum, and the way these are expressed through the form and dynamics of the pamphlet itself.

Noting that the texts of the pamphlets are readily available on its Web site, and so foregrounding the artifactual nature of the pamphlet, Infopool argues that "taking the form of pamphlets is not irrelevant. Using a small press, or post-media form, implies that they are documents that are circulated in extremely small numbers. They are, in a sense, intimate and specific and, crucially, the communication they aim for is one that is unmediated. 
In short the pamphlets, infopool projects, are concerned with developing their own contexts."72 The pamphlet here is "self-institutional" — not unlike Benjamin's collected object, though now with an explicit social inflection, it constitutes contexts, affects, and modes of exchange. And it does so in a fashion infused with "vulnerability." As objects without copyright they extend a "contract of 'trust" " concerning a "sensitivity" toward content and aim in an "unprotected offer of communication." 73 In contrast to instances of political expression founded upon and constitutive of institutional authority, this vulnerability is a key value of the pamphlet's self-institution. The pamphlet is an expressive arrangement that, as a self-published entity, requires of its producer only the "little power" of "intension." " And this little power expressed in material form in turn affirms the emergent and exploratory nature of the collective states that are articulated, or held, in its encounters. As such, "the vulnerability of the pamphlet is also its power," its particular value as an undetermined field of association. ${ }^{75}$

Some appreciation of these qualities must have figured in the Tate's interest in the pamphlets, but its engagement is manifest in the blunt and clumsy transformation of the dynamic, self-institutional object into an inert object of property, an artifact of exhibition. This is a practice that can be seen with Infopool as an attempt at the "valorisation of socialisation" that is endemic to contemporary cultural institutions, yet one that in its very action shows the institution's inability to handle such emergent relations. ${ }^{76}$ In its new guise, the pamphlet's values of autonomy, tentative self-institution, and chance are converted into exhibition value, the value, as Arvatov has it, of "murdered objects" "hidden under glass": ${ }^{77}$

On display in a new hardback cover and threaded through with wire (the new vitrine) the pamphlets take on an aura that undermines both their form and content. They are no longer able to be passed on, given as gifts, and circulated to friends and fellow travelers, i.e. to be self-institutional. In short the pamphlets have been commodified beyond their informal and nominal $£ 1.00$ price. The generator of value that is the Tate Modern has allotted them an immaterial cultural value (prestige, distinction) in exchange for the appearance of the value of their autonomy. ${ }^{78}$

\section{The Expressive Terrain of Paper}

Far from a mere substratum or support, paper is a complex and sensual entity - for Jacques Derrida, "paper . . . gets hold of us bodily, and through every sense" 79 - and is central to the peculiar physical and sensorial terrain of the pamphlet. In his anatomy of the emergence and form of the pamphlet in early modern Britain, Joad Raymond shows that the properties and economies of paper had a key role. ${ }^{80}$ The pamphlet was a stitched rather than bound quarto, a size that allowed for the use 
of smaller, cheaper paper at a time when this material comprised up to three-quarters of printing costs. It would typically number between one and twelve sheets, giving between eight and ninety-six pages in total and would normally be produced in editions of 250 to 1,500 . Raymond places considerable emphasis on its physical attributes, arguing that "some of the most fundamental aspects of the pamphlet" were "its appearance, size, weight, texture"; "readers knew what a pamphlet looked like, and how it felt in the hand." 81 The feel, diminutive and ragged form, and relative lack of commercial value also played a role in the meaning and cultural associations of the pamphlet, which, though it rose to some degree of recognition and influence in the seventeenth century, existed - unlike the manuscript, the book, and later the newspaper - as a somewhat disreputable entity. This is especially clear in Raymond's assessment of the common perception of this medium in the late sixteenth century: "Pamphlets were small, insignificant, ephemeral, disposable, untrustworthy, unruly, noisy, deceitful, poorly printed, addictive, a waste of time." 82

Something of the base nature of its materials persists as a defining feature of the pamphlet through the twentieth century. The Russian Futurist books and pamphlets of the 1910s were produced in very small editions using cheap paper and ephemeral materials, including burlap and wallpaper. In the clandestine "samizdat" of the Soviet bloc the functionality of carbon paper for illicit domestic reproduction made it a common material, and even today, with popular access to desktop publishing, strategies deployed in the production of self-published print media often eschew the overly smooth and professional visual aesthetic (typified by Wired magazine) that such technologies enable (figure 2). Similarly, the physical attributes of the pamphlet continue to be central to its material and sensory nature: its texture and feel, the variable smell of paper dependent on age and condition, the quality of the print, the physical act of turning the page. One does not need to pose an opposition between analog and digital media to recognize the specific properties and pleasures of print: "All books are visual. . . A All books are tactile and spatial as well - their physicality is fundamental to their meaning. Similarly, the elements of visual and physical materiality participate in a book's temporal effect - the weight of paper, covers, endpapers or inserts, fold-outs or enclosures all contribute to the experience of the book." 83

An attention to the physical qualities of the pamphlet - with Arvatov, to the "deepest sense of things" - is an enduring theme in Infopool. Insistent on the coimplication of the material with the conceptual and social aspects of the pamphlet, Jakobsen talks of Infopool pamphlets as expressing an "everyday materiality," a "materiality of available means," and suggests that - unlike the finished object of the mass-produced and perfect-bound book - the pamphlet "tells a story through its material," 


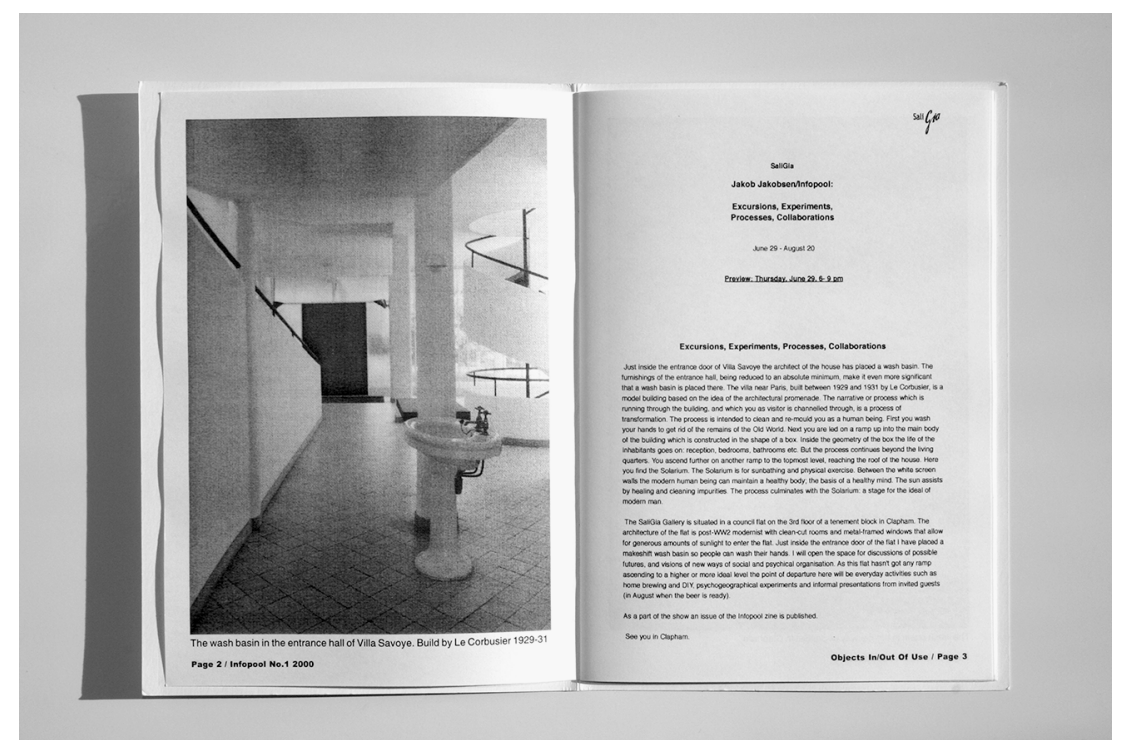

Figure 2. Pages from Infopool no. 1. Collection of the author

one that foregrounds the processes of its production, or the "practical task" of developing a pamphlet "as an individual, as a little entity." 84 The Infopool pamphlets are produced in a relatively inexpensive fashion with photocopied paper and covers assembled from metallic-silver card bought from an East London remaindered-stationery shop. The cover text includes a combination of print and script numerals, playfully indicating the handwrought nature of the object while, in the contrast between the two graphic technologies, foregrounding its existence at the interface of different circuits of production.

There is also here a revaluation of materials, following a concern with their processes of emergence and dissipation. Jakobsen explicitly addresses this theme in posing the question of the "new" through the construction of a table from discarded materials, a table connected to the selfinstitution (as site of display and discussion) of the Infopool pamphlet. ${ }^{85}$ Here Jakobsen comments on Baudelaire's ragpicker - a figure Benjamin closely associates with the collector ${ }^{86}$ - in terms of the creation of value from the gray zone between waste and utility, a practice disavowed in the Global North by the consumer object and its temporal patterns of novelty and obsolescence. Yet for Jakobsen, the revaluation of material is extant not simply in economy but also in unsettling the social and economic partitions of waste and value as the material is valorized in its new social arrangements - what Jakobsen, after the Danish artist Asger Jorn, calls a "non-monetary surplus value." 


\section{Ephemeral Duration}

Each pamphlet has a variable duration, dependent on its point of intervention, mode and extent of circulation, associated event, popularity of theme, and so on; for Jakobsen, "the specificity of any of these self-publications is that they have their own time." 88 Such atypical specificity is alloyed with a strong ephemeral aspect, a tendency to fall out of circulation, get lost, or accumulate in a stack of documents. Indeed, the pamphlet has for much of its history been treated as a disposable object, a property clear in Thomas Bodley's interdiction against preserving pamphlets at (what was to become) Oxford's Bodlein Library as a medium "not worth the custody in suche a Librarie." ${ }^{89}$

Yet this singular existence courted by destruction can express a positive political value, what can be called, after the fetish, a value of the "untransposable." It is a value that pervades the 56a Archive. This openaccess archive and reading room based at a social center in London's Elephant and Castle holds more than ten thousand items of radical ephemeral media - media associated with direct action, anarchist, queer, squatting, feminist, and Left communist politics. ${ }^{90}$ It was established in 1991, in part as an effect of the ephemerality of such media; as items circulated through the networks of radical groups and individuals that used the center, some accumulated to become the germ of the archive. ${ }^{91}$

Contrasting their practice with tendencies in radical librarianship that would preserve a set of pamphlets in a perfect-bound book, Chris talks of ephemerality as a fundamental feature of these media objects: "the ephemerality of the zine or pamphlet, that's what it's about. Zines come to you because they will." The pamphlet "makes trails" through an open set of encounters, and these encounters are registered on its body. ${ }^{92} \mathrm{An}$ attention to these characteristics is clearly in tension with the conventional archival imperatives of completeness and preservation, but instead of resolving the tension, the 56a Archive holds it open through a modulation of the ephemeral qualities of the pamphlet in the archive itself. Material continues to arrive in a largely ad hoc fashion, and the gentrification of inner London may well commit the collection to dispersal again, should the social center be closed under pressure from property values. Within the archive itself, an emphasis is placed on a tactile relation to the media objects collected, a "sensuality," a "conscious relationship to stuff," and one that allows for decay: "We just have the barest minimum, which is space full of things. And then time and climate does what it does, or weevils, or . . " (figure 3 )..$^{93}$

Far from suggesting that the pamphlet's temporality is only immediate, here ephemerality becomes, paradoxically, a quality that endures. It is a quality that permeates the object and colors its social encounters, 
providing a sense of the discontinuous and variegated nature of intellectual, political, and inorganic time. Benjamin's speculation that the object embodies times and sensations associated with previous owners and contexts can manifest here in terms of the object's association with, or expression of, particular political events, movements, or currents. This is how Chris frames his archival and affective relation to original editions of printed material, even when in a language he does not read or when an English translation is already archived: "What is that impulse? We're not talking about collecting trophies. We're talking about

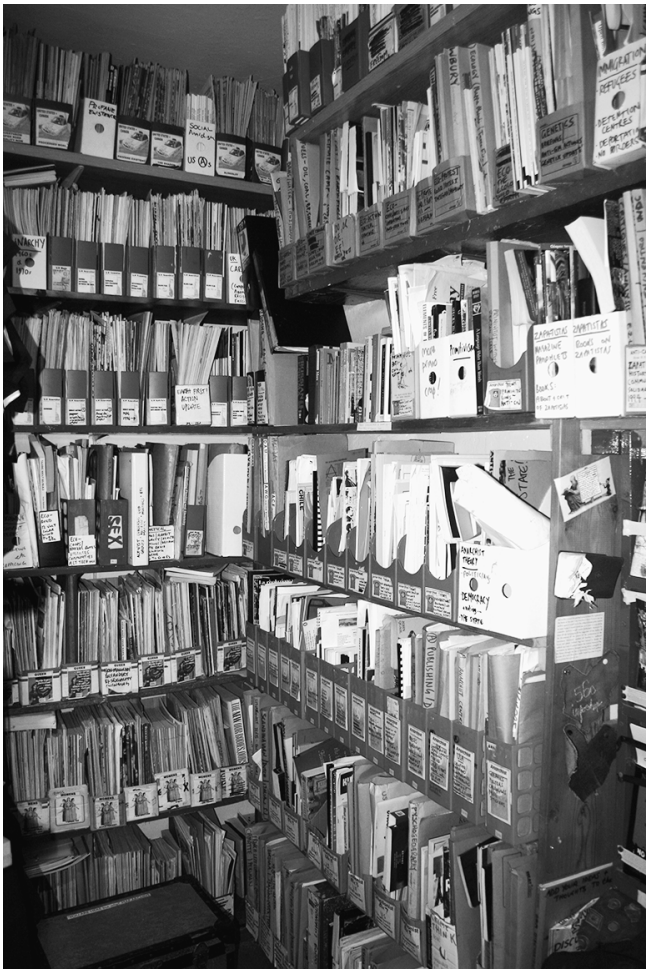

Figure 3. 56a Archive. Collection of the author a thing that has a desire for change, for revolutionary change." ${ }^{94}$ From the perspective of Benjamin's collector (after Proust), a trophy is the integrated object of linear, historical memory, the concern, as Leslie puts it, of the "souvenir-hunter." ${ }^{95}$ In Chris's formulation, one can detect a political inflection of a more undetermined charge, where memory is involuntary, "impromptu, bouncing off objects encountered randomly. It is lucid, pre-verbal, and coupled with euphoria." 96

This peculiar intensity of the media object can be destroyed, ironically, through efforts to overcome ephemerality. For Hollier, the materialist "document" has an intrinsic and affirmative relation to momentary instantiation, to "what does not last," an untransposable character he sees as particular to the journal Documents itself. ${ }^{97}$ When subject to the reprint - to preservation and iteration in the commercial publications of art history - the journal loses its value: "But it is for the kamikazes, for the most fleeting trackers of the avant-garde, those who have not even seen two winters, that the honor of the reprint is intended. He who wins loses." is a problem concentrated in the conceptualization of the poster developed at Atelier Populaire, the occupied École des Beaux-Arts in the Paris revolts 
of 1968, where some 600,000 silk-screen stencil posters were fabricated in 350 designs. ${ }^{99}$ For Atelier Populaire, the integration of media with situated political practice was so tight that it not only opposed the sale of the object, or a distracted appreciation of its aesthetic value, but deemed even archival preservation beyond the event a violation of its consistency:

To use [the posters] for decorative purposes, to display them in bourgeois places of culture or to consider them as objects of aesthetic interest is to impair both their function and their effect. This is why the Atelier Populaire has always refused to put them on sale.

Even to keep them as historical evidence of a certain stage in the struggle is a betrayal, for the struggle itself is of such primary importance that the position of an "outside" observer is a fiction which inevitably plays into the hands of the ruling class. ${ }^{100}$

I would not deny the importance of this move toward an immediate and irrevocable consumption of political art in the event. But the point to extract is that this configuration actually contributes to the persistent vitality of an object of 1968 today, a vitality that is expressive of that extrahistorical event precisely in the object's resistance to preservation.

There may be more external factors in the destruction of singular and ephemeral media objects. In 1970s Italy, for example, the possession of radical literature was regularly used as an indication of guilt in the mass arrests and prosecutions of the Autonomia movement such that it was common practice for militants to destroy this material. In Negri's case, following the inclusion of "the publication and distribution of pamphlets and communiqués that incite armed insurrection" in the charges against him, his pamphlets such as Domination and Sabotage and Workers Party against Work were pulped by the publisher, Feltrinelli. ${ }^{101}$ Of course, the presence of the state in the practice of destruction in no way negates the notion that ephemeral media objects "have their own time."

\section{Seductive and Unpopular Objects}

For the properties I have been describing, the pamphlet can be a rather seductive object. A certain seduction is actually present in the etymology of the word pamphlet, derived from the Greek pamphilos, meaning "loved by all," and coming to name this object via the lead character of a popular twelfth-century love poem, Pamphilus seu de Amore. ${ }^{102}$ But what I want to consider here is the contemporary pamphlet's disruptive interaction with the seductions of the commodity.

An object in its commodity mode is universally enticing. For Benjamin, it has a most "empathetic soul": "If the soul of the commodity which Marx occasionally mentions in jest existed, it would be the most empathetic 


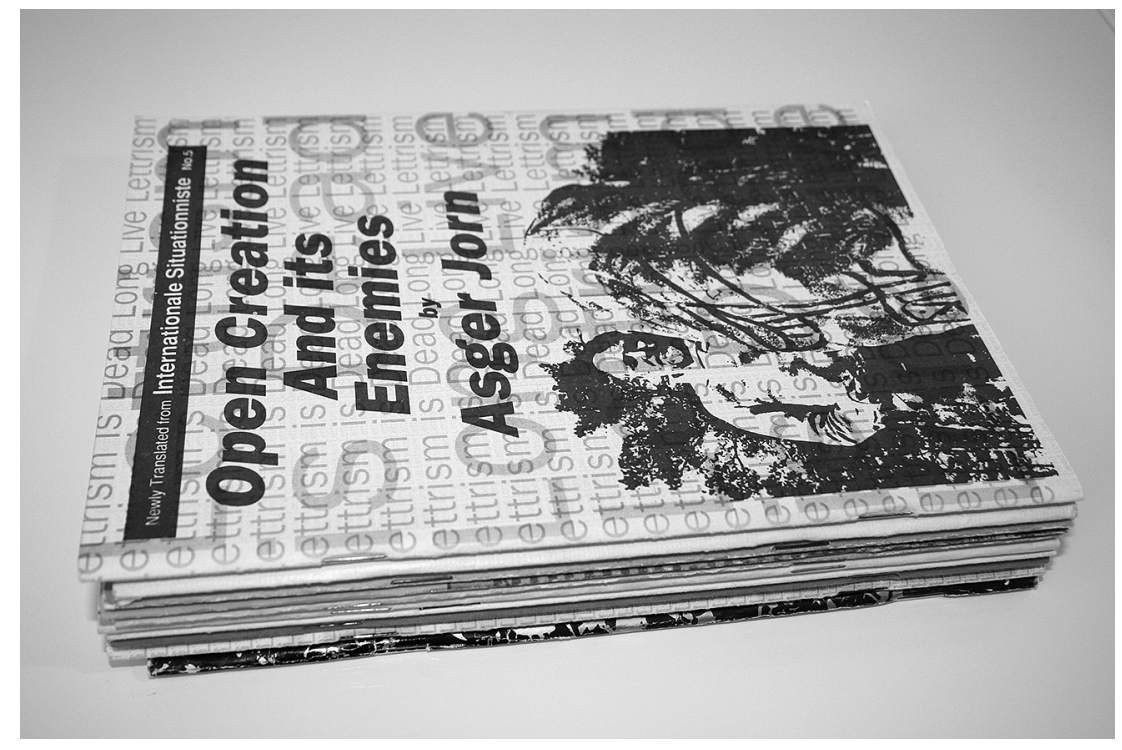

Figure 4. Unpopular Books pamphlets. Collection of the author

ever encountered in the realm of souls, for it would have to see in everyone the buyer in whose hand and house it wants to nestle." 103 The pamphlet as communist object does not negate such attraction, but handles it in critical ways, as is evident in the practice of Unpopular Books. In discussing the experience of passing on some political texts to a third party overseas, Tompsett conveys a little of his unusual materialist approach to printed matter when he comments that he imagined the texts, wrapped up in a plastic sheeting block, as a "talisman." 104 The seductive quality of Unpopular Books' pamphlets themselves is constituted through an engagement with the arts and conventions of printing and the mechanisms by which commercial value attaches to printed matter. Unpopular Books arose out of Tompsett's involvement in London print cooperatives and the Rising Free bookshop and press (which published the first full English edition of Raoul Vaneigem's The Revolution of Everyday Life, a book that suffered from a poor knowledge of binding materials such that it became an "autodestructive commodity," "the perfect situationist book, it fell apart as you read it"). ${ }^{105}$ In contrast to the use of photocopy technology in Infopool, a print aesthetic has a strong presence in these pamphlets (figure 4). For Tompsett, print has its value in longevity, but he also describes the practice of printing with close attention to its material processes and sensations, framing the labor and value of printing in this fashion: "when you hear the term congealed labor you think of congealed ink. All the other printers do 
as well. ... We would watch the printing press as the paper passed through it and imagine it squeezing value into these pieces of paper."106

In this comment on production and value there is already a complex association of labor, sensation, and material process, but value also accrues through the structural form of the printed object and its subsequent life. With respect to the history of ephemeral print creations in the historical avant-garde, Tompsett talks of pamphlets as "cultural artifacts that accumulate value over time," an accumulation that is constituted through contingent cultural and economic practices and structures. ${ }^{107}$ One Unpopular Books edition can suffice as an example of the press's engagement with these layers of process and value.

As with most editions from this press, the pamphlet Open Creation and Its Enemies, which contains the first English translation of Asger Jorn's texts "Open Creation and Its Enemies" and "Originality and Magnitude (on the System of Isou)," was allocated an International Standards Book Number, and a copy was logged with the British Library. In this manner it is placed and validated in the conventional field of the commercial book as a uniform, iterable, and authoritative entity — and one should remember that it was precisely the standardizing properties of print technology that enabled the Guttenberg book to set the example of the modern commodity, being the first mass-produced industrial object. ${ }^{108}$ But Open Creation simultaneously troubles this regime, playing with the mechanisms that constitute it as a regular entity. The pamphlet was printed in contravention of the ISBN allocation regulations with two different covers (for consistency across the pamphlets - "the particular mix of colors," "the same moisture going into the paper" - they were set out simultaneously on the same A2 plates). ${ }^{109}$ A "Note to Librarians" on the back of each advises that the cover is merely a protectant for the text in transit and should be expunged to avoid confusion for future bibliographers. The inside covers each announce different Unpopular Books editions - A Trip to Edzell Castle and An English Hacienda - that remain unpublished. And, extending outward to the wider commercial field, an editorial commentary makes critical reference to a 1977 pamphlet by the U.S. pro-situationist group Capitalist Crisis Studies, noting that by documenting its existence the citation might inflate the price of "this curious and rather rare pamphlet." 110 The 1994 Open Creation pamphlet is itself a second edition; it notes a first that was printed in an issue of fifty to accompany a 1993 trip of the LPA to Calanais in the Outer Hebrides, an event associated with the commemoration of Jorn's death. Ritualizing the production, circumstance, and anomalous value of the object - something Tompsett associates with Jorn's understanding of magic and fabrication ${ }^{111}$ - Tompsett holds a copy of this edition in a sealed envelope, posted from Calanais on the date of its publication. ${ }^{112}$ 
This fashioning of the media object through reflexive attention to its contexts and techniques of production and value is a repetition of the bibliographic self-consciousness that Raymond argues was a common motif of early modern pamphlet culture. It contributes to the rather inscrutable air common to Unpopular Books editions and has the effect of generating an enticing printed artifact. In this there is a tracking of the seductive field of the conventional book, but it is a seduction that draws much of its power from the slight distance the pamphlet creates from the structures that constitute the book as iterable commodity - the pamphlet is not an autonomous entity wholly outside the structural patterns of the commercial book, but operates in its midst as a mimic. In significant ways the pamphlet's attractions are also more directly cut away from the commodity mode of the book. Unpopular Books pamphlets have a price that bears little relation to their costs of production. If they have often been produced in the downtime between commercial print runs - after Rancière, in the nights of labor - Tompsett also frames the product and process of production of the pamphlet as constitutive of the excesses of the "potlatch," the extravagant gift. Indeed, the LPA would surreptitiously place such pamphlets in book and charity shops encountered on their excursions - a "negative shoplifting." 113

Neither demanding commercial exchange nor valorizing the labor of its production, the pamphlet can also unsettle the commodity's expansive, generic "empathy." In contrast to the dominant mode of marketing commercial books today (even the most difficult works of theory and critique), the Unpopular Books pamphlet withdraws from or actively refuses the imperatives of expansive appeal; in Mallarmé's words, it "does not demand the approach of a reader." 114 These pamphlets have no need to be consumed simply for the sake of turnover. Relieved of this, their seductions can be emergent to their assorted encounters, with all the gradations of affect such encounters produce. And here there is an additional relay between the sensual properties of the object and its politico-conceptual content-not only its anticommodity orientation but also its critique of dominant modes of political organization. For, as Tompsett describes it, in the critical exploration of unsettling themes and received political truths, the content of these pamphlets does not invite an audience, seek followers, or flatter an established political community.

In concert with its seductive material quality, then, the Unpopular Books pamphlet remains a resistant, unsettling entity. It is, to borrow from the name of the press, an unpopular object. In a political venture this may appear perverse but is not so. It is in fact a material expression of the communist opposition to concentrated blocs of semiotic and organizational authority - following, instead, the imperative toward distributed and emergent self-critical composition. ${ }^{115}$ It is thus from Marx that 


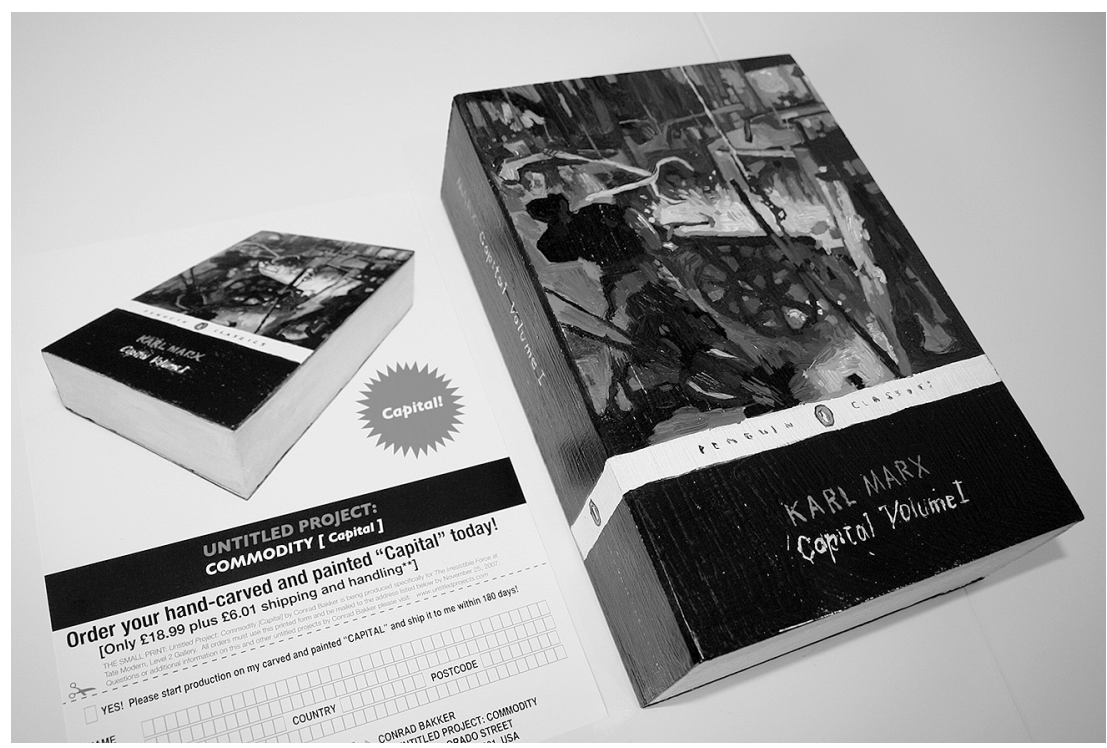

Figure 5. Conrad Bakker, Untitled Project: Commodity [Capital]. Courtesy of Conrad Bakker

Tompsett derived the name and valence of the press: "Both of us scoff at being popular. Among other things our disgust at any personality cult is evidence of this. ... When Engels and I first joined the secret society of communists, we did it on the condition sine qua non that they repeal all statutes that would be favorable to a cult of authority."116

\section{Conclusion}

The book and its margins may seem a too obvious focus for investigation of communist themes, given the relatively free reign that it has allowed to the expression of communist ideas. But this would be to focus on the book only as textual and conceptual content, not as complex material object. Editions of Capital, for instance, are not principally communist objects; as recently explored in Conrad Bakker's hand-carved and -painted mail-order replicas of Marx's book, a dominant modality of Capital is the commodity (figure 5). ${ }^{117}$ The prevalent tendency to perceive the book divorced from its material forms and orbits, despite its historically intimate relationship with industrial production, is in part a product of modern commercial publishing. As Trish Travis argues, publishing has couched its advanced industry in a discourse that articulates the book as an object immune to commodification, "goods which pretend not to be goods at all." This has a somewhat ironic benefit in the impetus it gives the book as a site of projection beyond capital: "By the specific ways in which they participate in 
and shape the world of goods, books allow us to believe that there is an escape from or an alternative to that world." 118 Nevertheless, what Travis describes as this "transcendent identity" rather discourages a politics of the rich materiality of printed media, the specific concern of this article.

Any discussion of the politics of the printed object today warrants a little reflection on its place in the wider media environment. That the digital medium, blogs and mailing lists in particular, has taken to itself some of the unique attributes of the political pamphlet (while also articulating and reconfiguring them within its own open set of distributive, interactive, and archival properties) is not in doubt. In this context, the nature and function of political printed matter is certainly undergoing change. ${ }^{119}$ When the pamphlet is understood as a complex material object rather than a simple means of the propagation of information, however, the adequacy of digital media as a substitute is less assured. It is noteworthy that while recent years have seen a diminution in the volume of political pamphlets, in art practice - a field often more in tune with the dynamic qualities of matter and sensation - the self-published print medium has of late come to some prominence. This has been evident not only in recent high-profile exhibitions in London of historical print media (Documents magazine at the Haywood Gallery in 2006, Futurist and avant-garde books at the British Library in 2007-8, and book arts at the Victoria and Albert Museum in 2008) but also in a practitioner field sustained by small-press and self-publishers' fairs such as London's Publish and Be Damned, New York's NY Art Book Fair, the global touring archive KIOSK: Modes of Multiplication, and book art centers like Minnesota's Open Book and New York's Printed Matter. ${ }^{120}$ Contemporary art, then, suggests the possibility for print media to continue inventive and dynamic interventions in the variegated media environment - an environment not best approached through a delimiting conception of print and digital media in a linear relation of succession. Of course, if communist media practice can learn from this, there is no reason for it to be confined to print, far from it. It is toward an expanded understanding of the material field of political media that this article is oriented.

\section{Notes}

I am most grateful to Jakob Jakobsen, Chris, and Fabian Tompsett for their time and conversation and to them and Conrad Bakker for permission to reproduce images of their work. I would also like to thank Eleanor Wright for discussion of Benjamin's collector and Stephen Zepke, Graeme Kirkpatrick, and the Social Text reviewers for their incisive comments. The research for this article was undertaken during leave funded by the ESRC Centre for Research on Socio-Cultural Change.

1. See David Finkelstein and Alistair McCleery, eds., The Book History Reader (London: Routledge, 2002); Jerome Rothenberg and Steven Clay, eds., A Book of the 
Book: Some Work and Projections about the Book and Writing (New York: Granary, 2000); Johanna Drucker, The Century of Artists' Books (New York: Granary, 2004).

2. Jacques Rancière, The Nights of Labor: The Workers' Dream in the Nineteenth

Century, trans. John Drury (Philadelphia: Temple University Press, 1989), 8.

3. Rancière, cited in Donald Reid, "The Night of the Proletarians: Deconstruction and Social History," Radical History Review 28-30 (1984): 460.

4. Walter Benjamin, Reflections, trans. Edmund Jephcott (New York: Schocken, 1978), 61; Walter Benjamin, Illuminations, ed. Hannah Arendt, trans. Harry Zohn (Harmondsworth, UK: Fontana, 1992), 68.

5. Christina Kiaer, Imagine No Possessions: The Socialist Objects of Russian Constructivism (Cambridge, MA: MIT Press, 2005), 33.

6. Aleksandr Rodchenko, quoted in Kiaer, Imagine No Possessions, 199.

7. Kiaer, Imagine No Possessions, 7.

8. Boris Arvatov, "Everyday Life and the Culture of the Thing (Toward the Formulation of the Question)," trans. Christina Kiaer, October 81 (1997): 126.

9. Kiaer's translation notes point out that Trotsky's position in "Proletarian Culture and Proletarian Art" is the main target of Arvatov's critique.

10. Arvatov, "Everyday Life and the Culture of the Thing," 120.

11. Ibid., 121, 126.

12. Ibid., 123.

13. Ibid., 123, 124.

14. Karl Marx, "Economic and Philosophical Manuscripts," trans. Gregor Benton, in Early Writings (Harmondsworth, UK: Penguin, 1975), 352.

15. Arvatov, "Everyday Life and the Culture of the Thing," 122.

16. Marx, "On the Jewish Question," trans. Gregor Benton, in Early Writings, 229.

17. Karl Marx, Capital: A Critique of Political Economy, vol. 1, trans. Ben Fowkes (New York: Penguin, 1976), 163-77. These comments on commodity fetishism are informed by Peter Stallybrass's wonderful essay "Marx's Coat," in Border Fetishisms: Material Objects in Unstable Spaces, ed. Patricia Spyer (New York: Routledge, 1998), 183-207.

18. Arvatov, "Everyday Life and the Culture of the Thing," 121, 124.

19. Marx, "Economic and Philosophical Manuscripts," 352, 390.

20. Peter Pels, "The Spirit of Matter: On Fetish, Rarity, Fact and Fancy," in Spyer, Border Fetishisms, 101.

21. Arvatov, "Everyday Life and the Culture of the Thing," 126.

22. Boris Arvatov, "From Art and Class (1923)," in The Tradition of Constructivism, ed. Stephen Bann (London: Thames and Hudson, 1974), 45, 46.

23. Maria Gough, cited in Kiaer, Imagine No Possessions, 49.

24. Arvatov, "Everyday Life and the Culture of the Thing," 127. I should note that Arvatov's argument also contains a more conventional understanding of the conquest and mastery of nature.

25. Ibid., 128.

26. Gilles Deleuze and Félix Guattari, A Thousand Plateaus: Capitalism and Schizophrenia, Volume 1, trans. Brian Massumi (London: Athlone, 1987), 411. For development of the aesthetic dimensions of "nonorganic life," see Stephen Zepke, Art as Abstract Machine: Ontology and Aesthetics in Deleuze and Guattari (New York: Routledge, 2005), 141-45.

27. Arvatov, "Everyday Life and the Culture of the Thing," 48, 47.

28. Gilles Deleuze and Félix Guattari, "Balance-Sheet Program for Desiring 
Machines," trans. Robert Hurley, in Guattari, Chaosophy, ed. Sylvère Lotringer (New York: Semiotext(e), 1995), 119-50.

29. For discussion of this problem in Marxism, see Nicholas Thoburn, Deleuze, Marx and Politics (London: Routledge, 2003), 73-80.

30. Walter Benjamin, The Arcades Project, trans. Howard Eiland and Kevin McLaughlin, ed. Rolf Tiedemann (Cambridge, MA: Harvard University Press, 2002), 9.

31. Ibid., 209 (emphasis added).

32. Marx, "Economic and Philosophical Manuscripts," 351.

33. Ibid., 352 .

34. Benjamin, Arcades Project, 205, 206.

35. Esther Leslie, "Telescoping the Microscopic Object: Benjamin the Collector," in The Optic of Walter Benjamin, ed. Alex Coles (London: Black Dog, 2001), 80; Benjamin, Arcades Project, 206.

36. Benjamin, Illuminations, 62.

37. Benjamin, Arcades Project, 204.

38. Benjamin, Illuminations, 62, 69 (emphasis added).

39. Félix Guattari, Chaosmosis: An Ethico-Aesthetic Paradigm, trans. Paul Baines and Julian Pefanis (Sydney: Power, 1995), 131.

40. Benjamin, Illuminations, 250-51.

41. See Ackbar Abbas, "Walter Benjamin's Collector: The Fate of Modern Experience," in Modernity and the Text: Revisions of German Modernism, ed. Andreas Huyssen and David Bathrick (New York: Columbia University Press, 1989), 232.

42. Benjamin, cited in Erdmut Wizisla, preface to Walter Benjamin's Archive: Images, Texts, Signs, ed. Ursula Marx, Gudrun Schwarz, Michael Schwarz, and Erdmut Wizisla, trans. Esther Leslie (London: Verso, 2007), 5.

43. Walter Benjamin, Charles Baudelaire: A Lyric Poet in the Era of High Capitalism, trans. Harry Zohn (London: Verso, 1983), 181, 182.

44. André Breton, Mad Love, trans. Mary Ann Caws (Lincoln: University of Nebraska Press, 1988), 126.

45. Ibid., 25-38.

46. Denis Hollier, "The Use-Value of the Impossible," trans. Liesl Ollman, October 60 (1992): 20.

47. Ibid., 22.

48. Pels, "Spirit of Matter," 99.

49. William Pietz, “The Problem of the Fetish, I," Res 9 (1985): 5, 7.

50. Pels, "Spirit of Matter," 98.

51. Ibid.

52. William Everson, "From The Poem as Icon-Reflections on Printing as a Fine Art," in Rothenberg and Clay, Book of the Book, 50.

53. Drucker, Century of Artists' Books, 2.

54. Aleksei Kruchenykh, "New Ways of the Word (The Language of the Future, Death to Symbolism)," in Russian Futurism through Its Manifestoes, 19121928, ed. Anna Lawton, trans. Lawton and Herbert Eagle (Ithaca, NY: Cornell University Press, 1988); Nikolai and David Burliuk, "Poetic Principles," in Lawton, Russian Futurism through Its Manifestoes, 82.

55. Aleksei Remizov, cited in Nina Gurianova, " 'A Game in Hell, Hard Work in Heaven': Deconstructing the Canon in Russian Futurist Books," in The Russian Avant-Garde Book 1910-1934, ed. Margit Rowell and Deborah Wye (New York: Museum of Modern Art, 2002), 26. 
56. Jared Ash, "Primitivism in Russian Futurist Book Design 1910-14," in Rowell and Wye, Russian Avant-Garde Book, 33-40; Gurianova, "'Game in Hell, Hard Work in Heaven.'”

57. Viktor Shklovskii, cited in Gurianova, "Game in Hell, Hard Work in Heaven," " 31. or amulet.

58. Gris-gris, the noun Artaud uses for these works, signifies charm, fetish,

59. See Margit Rowell, ed., Antonin Artaud: Works on Paper (New York: Museum of Modern Art, 1996).

60. Agnès de la Beaumelle, "Spells and Gris-Gris 1937-1944: Introduction," in Rowell, Antonin Artaud, 40.

61. Ibid., 40.

62. Antonio Negri, "Postface to the Complete Text of the Journal Futur Antérieur (1989-98)," trans. Ed Emery, 31 May 2004, Multitudes Web 3, multitudes .samizdat.net/spip.php?article1497 (accessed 5 June 2008).

63. Drucker, Century of Artists' Books, 358, 8.

64. Iain Sinclair, Lights Out for the Territory: Nine Excursions in the Secret History of London (London: Granta, 1997), 25.

65. See Guestroom, www.guest-room.net (accessed 5 June 2008).

66. Stéphane Mallarmé, “The Book: A Spiritual Instrument,” trans. Bradford Cook, in Critical Theory since Plato, ed. Hazard Adams (New York: Harcourt Brace, 1971), 690, 691.

67. Gilles Deleuze, The Fold: Leibniz and the Baroque, trans. Tom Conley (Minneapolis: University of Minnesota Press, 1993), 31.

68. Drucker, Century of Artists' Books, 358.

69. Henriette Heise and Jakob Jakobsen, "Info 2," Infopool, www.infopool .org.uk/Files/ic.htm (accessed 5 June 2008). The collaborative practice at Infopool has included a number of people, most especially Anthony Davies, Emma Hedditch, and Howard Slater.

70. For more on these institutions, see www.infopool.org.uk/ and www.copen hagenfreeuniversity.dk/.

71. Infopool, “Operation Re-appropriation: Infopool @ Tate Modern, 9.2.2001," Infopool, www.infopool.org.uk/tate/htm (accessed 5 June 2008).

72. Ibid.

73. Ibid.

74. Jakob Jakobsen, interview by the author, London, 16 July 2007.

75. Ibid.

76. Infopool, "Operation Re-appropriation."

77. Arvatov, cited in Kiaer, Imagine No Possessions, 68.

78. Infopool, "Operation Re-appropriation."

79. Jacques Derrida, Paper Machine, trans. Rachel Bowlby (Stanford, CA: Stanford University Press, 2005), 42.

80. Joad Raymond, Pamphlets and Pamphleteering in Early Modern Britain (Cambridge: Cambridge University Press, 2003).

81. Ibid., 38, 39.

82. Ibid., 10.

83. Drucker, Century of Artists' Books, 197.

84. Jakobsen, author interview.

85. Jakob Jakobsen, "A New Table, Which Might Not Be Understood as Clean in Modern Terms," Infopool, www.infopool.org.uk/Files/ic.htm (accessed 5 June 2008). 
86. Abbas, "Walter Benjamin's Collector."

87. Jakobsen, author interview.

88. Ibid.

89. Thomas Bodley, cited in Raymond, Pamphlets and Pamphleteering, 5.

90. See “56a Infoshop,@n@archive,"56a,www.56a.org.uk/archive.html (accessed 9 December 2009).

91. Chris, interview by the author, London, 12 July 2007.

92. Ibid.

93. Ibid.

94. Ibid.

95. Leslie, "Telescoping the Microscopic Object," 68.

96. Ibid.

97. Hollier, "Use-Value of the Impossible," 23.

98. Ibid., 23. The 2006 Undercover Surrealism exhibition on Documents at London's Hayward Gallery offered an alternative possibility for returning to historical cultures of printed matter through the very unusual approach of exhibiting the heterodox material objects or "documents" whose images filled the pages of the journal. The curators sought to present not a movement or school, but "the magazine itself as an active force." The catalog glosses this active force as the magazine's "core ideas" - these being "the means of presenting the objects they made extraordinary" - rather than the wider material properties of the journal as a whole, but the resonance held between object, idea, and journal in the space of the gallery did much to articulate Documents as an open and vital material field. See Dawn Ades and Fiona Bradley, introduction to Undercover Surrealism: Georges Bataille and Documents, ed. Ades and Simon Baker (London: Hayward Gallery, 2006), 15.

99. Andrew Feenberg and Jim Freedman, eds., When Poetry Ruled the Streets: The French May Events of 1968 (Albany: State University of New York, 2001).

100. Atelier Populaire, Posters from the Revolution: Paris, May 1968 (London: Dobson, 1969), (emphasis added).

101. This quotation from Judge Achille Gallucci's 1979 warrant is cited in the introduction to Antonio Negri, Books for Burning: Between Civil War and Democracy in 1970s Italy, ed. Timothy S. Murphy, trans. Arianna Bove, Ed Emery, Timothy S. Murphy, and Francesca Novello (New York: Verso, 2005), xiii.

102. Raymond, Pamphlets and Pamphleteering, 7.

103. Benjamin, Charles Baudelaire, 55.

104. Fabian Tompsett, interview by the author, London, 5 June 2007.

105. Ibid.

106. Ibid.

107. Ibid.

108. Benedict Anderson, Imagined Communities: Reflections on the Origin and Spread of Nationalism (New York: Verso, 1991), 34.

109. Tompsett, author interview.

110. See Asger Jorn, Open Creation and Its Enemies, trans. Fabian Tompsett (London: Unpopular Books, 1994), 47.

111. See Simon Crook, "Moving Mountains: 'Shamanic' Rock Art and the International of Experimental Artists," Transgressions: A Fournal of Urban Exploration 4 (1998): 36-48.

112. Tompsett, author interview.

113. Ibid.

114. Mallarmé, cited in Maurice Blanchot, The Book to Come, trans. Charlotte Mandell (Stanford, CA: Stanford University Press, 2002), 229. 
115. For elaboration of this point through an approach to Marx's party as a distributive "diagram," see Nicholas Thoburn, "What Is a Militant?" in Deleuze and Politics, ed. Ian Buchanan and Thoburn (Edinburgh: Edinburgh University Press, 2008), 98-120.

116. Marx, cited in Jacques Camatte, This World We Must Leave and Other Essays, ed. Alex Trotter (New York: Autonomedia, 1995), 20.

117. Conrad Bakker's Untitled Project: Commodity [Capital] was exhibited at the Irresistible Force at London's Tate Modern in 2007 and was temporarily available for mail order at a price that mirrored that of the Penguin edition.

118. Trish Travis, "Ideas and Commodities: The Image of the Book," MIT Communications Forum, 1999, web.mit.edu/comm-forum/papers/travis.html, (accessed 5 June 2008).

119. It may indeed be this very change that is provoking contemporary investigation of the complex materiality of print, "liberat[ing] our reading for a retrospective exploration of the past resources of paper, for its previously multimedia vectors." Derrida, Paper Machine, 47.

120. These fairs and institutions have all been established since 2000, with the exception of Printed Matter, founded by Lucy Lippard, Sol LeWitt, and others in 1976. 